\title{
The Effect of Services Quality on Tourist Satisfaction and Tourist Loyalty
}

\author{
${ }^{1}$ STKIP PGRI West Sumatera, Padang City 25137, Indonesia \\ ${ }^{2}$ Padang State University, Padang City 25137, Indonesia \\ *Corresponding author. Email: neffisulkaisi10@gmail.com
}

Neffi Sulkaisi ${ }^{1, *}$, Idris $^{2}$, Felia Siska $^{1}$ and Irwan $^{1}$

\begin{abstract}
This study explores the influence of service quality variables, tourist satisfaction and tourist loyalty. This study involved 156 tourists who visited the Aditywarman Museum, then analyzed using the SEM method. The results showed that there is a direct influence between the variable service quality on tourist satisfaction and tourist loyalty and an indirect influence between service quality and tourist loyalty through tourist satisfaction variables.
\end{abstract}

Keywords: Services; Satisfaction; Loyalty; SEM

\section{INTRODUCTION}

In recent years, the event of the tourism industry has become an increasingly important research and policy topic. Consistent with the UNWTO (2018), a growing number of nations consider tourism to be the simplest alternative for economic recovery. However, the sole thanks to achieving sustainable tourism development are to produce every tourist with a satisfying and memorable travel experience, (Mossberg; 2007). One country that's been developing tourism in Indonesia, specifically the town of Padang.

Under regional development goals and therefore the Padang Municipality plan, it's been established that the town of Padang functions as a middle for development and "Doors the gate" of tourism in West Sumatra. The town of Padang has a bonus in sector tourism. Padang city has diverse and interesting tourism objects to be developed, like art tourism, nature tourism, historical and archeological tourism, traditional and cultural tourism which are interesting to go to. One every one of the attractions within the city of Padang is that the Adityawarman Museum, from 2014 to 2019 visitors to the Adityawarman Museum experience fluctuations each year. With the event of lifestyles and tourism objects increasingly touch the daily lives of everyone. Travel and vacation have become a priority, so each tourist attraction must provide quality services to be able to Amid the Emergent of recent Attractions.

The weightiness of this research is thanks to the importance of the tourism industry in Indonesia, especially the town of Padang. The tourism industry plays a vital role in the economic process of the town of Padang and therefore the Adityawarman Museum contributes to the economic process of the town of Padang through local revenue (PAD). Therefore, tourism should receive serious attention from the government regarding the standard services they provide to tourists.

The aim of this research is of this study is to research the influence of intermediates services quality on tourist satisfaction and tourist loyalty, the influence of tourist satisfaction on tourist loyalty, and therefore the effect of service quality on tourist loyalty that's mediated by tourist satisfaction. Travelers who like traveling they're trying to find our satisfaction with the standard of service they receive. Satisfied tourists will become loyal to the tourist attraction. The statement is supported by the results of the study of the authors try this standard of service encompasses a positive effect on satisfaction and loyalty and indirectly affects the standard of service on tourist loyalty mediated by tourist satisfaction. From the background and in step with previous experts who stated that service quality features a positive effect on tourist satisfaction and loyalty; (Keshavarz and Ali 2016). The author is fascinated by doing this research, but the authors add a mediating variable to live the indirect effect between service quality on tourist satisfaction and tourist loyalty.

\section{LITERATURE REVIEW}

\subsection{Services Quality}

The success of a public institution is Inseparable from the standard of the services they provide to service users. This becomes a necessity for the bureau to concentrate on the services they supply to users of their services. Over the past few decades, the standard of service has attracted plenty of attention from practitioners. Gronroos (1984), defines service quality as a result of the evaluation process, within which the customer compares his expectations with the service he feels while he's receiving. Factors that influence service quality parasuraman (1996), namely (1) 
personal needs, (2) past experience, (3) word of mount communication (4) external communication. Thus the standard of service is produced by the provision of adequate facilities, additionally to the existence of operations that have many factors in determining the success of the management of a tourist attraction. Advances in technology and other fields require the tourism office as a tourist attraction manager to supply quality services.

The characteristics of service quality per Kotler (2016), service characteristics include (1) Intangible, (2) Inseparability and (3) Variability. This study uses a service quality approach that's widely used as a reference in research is that the SERVQUAL (model service Quality). Per Parasuraman 1988, the service quality dimension (SERVQUAL) consists of 5 dimensions, namely: tangible, reliability, responsiveness, assurance, and empathy.

\subsection{Tourist Satisfaction}

According to Kotler (2016), satisfaction (satisfaction) is that the feeling of enjoyment or disappointment incurred for comparing the performance of a perceived product (result) to their expectations. If performance fails to satisfy expectations, the customer is going to be dissatisfied. If the performance is in line with expectations, the customer is satisfied. During this study the determinant indicators of satisfaction are (1) the amount of consumer or service user expectations, (2) the amount of performance provided by the corporate or service provider, this can be in line with research conducted by John Mardhatillah (1977) in serqual.

\subsection{Tourist Loyalty}

If tourist satisfaction concerns what's expressed by tourists, then tourist loyalty is said to what tourists do. Therefore satisfaction parameters are more subjective, harder to quantify, and tougher to live than tourist loyalty (Tjiptono, 2016). consistent with Valle, et al (2006) an indicator of a tourist said to be loyal are often assessed from

(1) intention to return (2) willingness to recommend.

\subsection{Conceptual Model and Research Hypothesis}

The conceptual framework could be a temporary conclusion from a theoretical review that reflects the connection between the variables studied. this can be a requirement to resolve problems in research and formulate hypothesis.

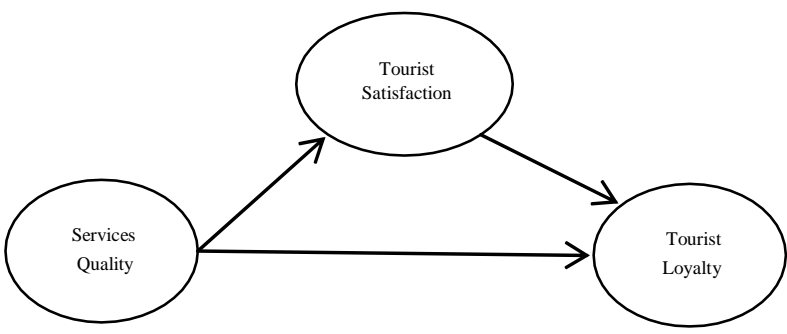

Figure 1. Conceptual Framework

\section{Hypothesis:}

Hypothesis made during this study are as follows

H1: Services quality encompasses a positive and significant effect on tourist satisfaction

$\mathrm{H} 2$ : Service quality contains a positive and significant effect on tourist loyalty

H3: Tourist satisfaction includes a positive and significant effect on tourist loyalty

H4: Tourist satisfaction has mediated the influence between service quality and tourist loyalty

\section{PROBLEM AND METHODOLOGY}

\subsection{Problem}

West Sumatra Province also has great potential for power tourist attraction is seen from the aspects of culture, natural conditions, flora and fauna, beautiful beaches and lakes, historical places, and so on. Tourism objects in West Sumatra Province, include Sianok Gorge, Anai Valley, Maninjau Lake, Singkarak Lake, Above Lake,

Dibawah Lake, Batu Malindundang and Mandeh Tourism Resort. Apart from its geographical and natural beauty, West Sumatra Province also has historic sites, high-value and unique cultural centers such as the Batu batikam in the Lima Kaum Tanah Datar. The building area, the tomb of the king in Tanah Datar. Jam Gadang, and Fort de Kock in Bukittinggi, Entering the era of globalization, for competing data in the tourism sector, it is very much determined by the quality of service provided by the service provider.

Of many tourist objects found in the city of Padang, the author writes about the Adityawarman Museum which is located at Jalan Diponegoro Number 10. The Adityawarman Museum Shas Various collections both from Minagkabau culture itself and from foreign collections.

The Adityawarman Museum has various collections both from Minangkabau culture itself and from foreign collections. The collections owned by the Adityawarman The data amount Travelers Museum Adityawarman from years 2014-2018can be seen in Table 1 . 
Table 1. Number of Tourists Visiting the Adityawarman Museum in 2014-2018

\begin{tabular}{|c|r|c|}
\hline Month & Amount & Percentage \\
\hline 2014 & 120,838 & \\
\hline 2015 & 124,382 & 1.03 \\
\hline 2016 & 124,556 & 1.00 \\
\hline 2017 & 126,884 & 1.01 \\
\hline 2018 & 130,469 & 1.03 \\
\hline
\end{tabular}

Source: Processed Data from the Adhityawarman Museum, (2019)

Based on the table above, it can be seen that visitors to the Adityawarman museum attraction has experienced an increase in visits every year by only $1 \%$ each year. Thus, it is appropriate for the manager of the Adityawarman Museum tourist attraction to improve the quality of services provided to visitors so that tourists visiting this tourist attraction will also increase and of course will affect the satisfaction and loyalty of tourists in the future.

Based on observations made by the author on May 1, 2019, the author found there were several small services but had a big impact on tourists visiting this museum, including the museum manager not providing a tour guide to explain the collections in the Adityawarman museum so that tourists do not know where to ask when having difficulty obtaining information, the information written in each collection is not detailed, such as the collection of which tribe the collection is on display, and there are also some museum rooms with no air conditioning. This causes visitors not to want to linger in the museum. Therefore, the management of the Adityawarman Museum tourist attraction should improve the quality of services they provide to tourists, so that, with the emergence of new tourist objects, the Adityawarman Museum is able to maintain its existence as a historical tourism object of superior quality. Tourist satisfaction is influenced by the quality of service.

According to Keshavarz and Ali (2015), they reveal that service quality directly affects tourist satisfaction and loyalty. The research that will conduct by the author also discusses the quality of service on satisfaction and loyalty, but the authors use an intervening variable, namely the satisfaction variable as a variable that mediates the influence between service quality variables and loyalty variables.

\subsection{Methodology}

In developing SEM models are that the search or development of models that have strong theoretical justification. A researcher must conduct a series of literature examinations to justify the theoretical model developed. During this study, a model that aims to research service quality influences on tourist satisfaction and tourist loyalty is going to be developed at the Adityawarman Museum. The research design during this study uses the Structural Equation Model (SEM) Test 23 with the subsequent models:

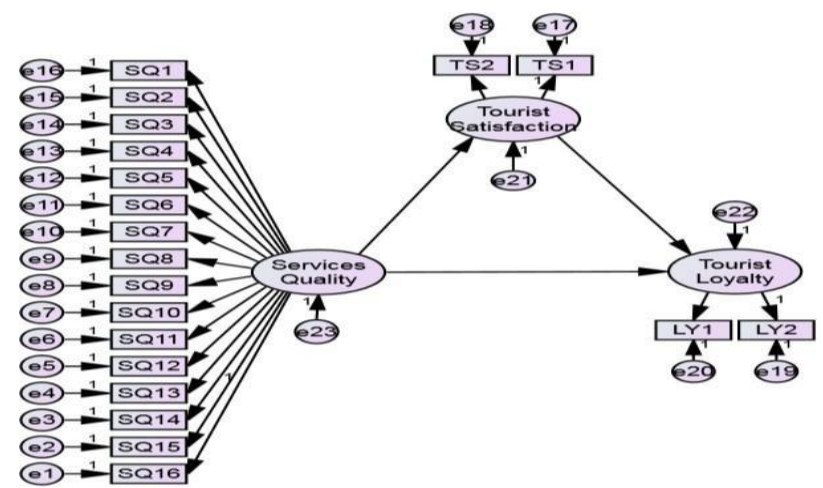

Figure 2. Structural Equation Model (SEM) of Research

The suitability of the model is evaluated by examining the SEM criteria. The primary action is to gauge whether the information used can meet the SEM assumptions namely sample size, normality, outlier, linearity, and multicollinearity and singularity. After that, the researchers tested suitability and tested statistics. Several suitability indices and cut-off values are wont to test whether the model is accepted or rejected.

Table 2. Goodness of Fit Cut-off Index

\begin{tabular}{cc}
\hline $\begin{array}{c}\text { Goodness Of } \\
\text { Fit Index }\end{array}$ & Cut-Off Value \\
\hline Chi-Square & Df A 0.05 \\
Probability & $\geq 0.05$ \\
RMSEA & $\leq 0.08$ \\
GFI & $\geq 0.80$ \\
AGFI & $\geq 0.90$ \\
TLI & $\geq 0.90$ \\
CFI & $\geq 0.90$ \\
\hline
\end{tabular}

Test Regression weight is completed to see the link between variables or not the effect of research. This test is allotted by analyzing the worth of Regression Weight, namely the worth of the critical ratio $(\mathrm{CR})$ required $\geq 1.96$ and Probability

(P) $\leq 0.05$ when the exercise results meet the wants, the hypothesis is accepted (Ghozali, 2008).

\section{RESULTS AND DISCUSSION}

\subsection{Results}

Below are the compositions of respondents supported gender, age work, income and are to the Adityawarman Museum. The findings of this study are as follows: 
Table 3. Descriptions of Respondents Characteristics

\begin{tabular}{|c|c|c|}
\hline Respondents & Frequency & Percent (\%) \\
\hline \multicolumn{3}{|l|}{ Gender } \\
\hline Female & 89 & 57 \\
\hline Man & 67 & 43 \\
\hline \multicolumn{3}{|l|}{ Age } \\
\hline $17-25$ Old & 66 & 42 \\
\hline $26-33$ Old & 46 & 29 \\
\hline $34-41$ Old & 26 & 17 \\
\hline $42-50$ Old & 11 & 7 \\
\hline 50 Old to the top & 8 & 5 \\
\hline \multicolumn{3}{|l|}{ Profession } \\
\hline Student & 9 & 6 \\
\hline College student & 14 & 9 \\
\hline Entrepreneur & 27 & 17 \\
\hline Civil Servants / & 87 & 56 \\
\hline \multicolumn{3}{|l|}{ Private Servants } \\
\hline Others & 9 & 12 \\
\hline \multicolumn{3}{|l|}{ Monthly income } \\
\hline There is no & 20 & 13 \\
\hline$\geq 1,000,000$ & 7 & 4 \\
\hline $1,000,000-3,000,000$ & 67 & 43 \\
\hline $4,000,000-6,000,000$ & 29 & 19 \\
\hline $7,000,000-$ & 22 & 14 \\
\hline $9,000,000,000$ & & \\
\hline$\leq 9,000,000$ & 11 & 7 \\
\hline \multicolumn{3}{|c|}{ Been to Adityawarman Museum } \\
\hline Yes & 156 & 100 \\
\hline No & 0 & 0 \\
\hline Number of visits & 59 & 38 \\
\hline 1 time & 69 & 44 \\
\hline 2 times & 19 & 12 \\
\hline 3 times & 9 & 6 \\
\hline
\end{tabular}

Based on the information above it is seen that the outline of the characteristics of respondents visiting the Adityawarman museum.

From table 1.2 it appears that the foremost dominant gender group is female with 89 people $(57 \%)$ and men with 67 people $(43 \%)$. the foremost dominant age was $17-23$ years with 66 people $(42 \%)$. The occupation status of the foremost dominant respondents is 87 civil servants / private employees $(56 \%)$. The foremost dominant monthly respondent income is earning 1 million to three million, as many as 67 people (43\%). Respondents who visited the Adityawaraman Museum 156 people (100\%) said that they'd "yes" visited the Museum. the number of dominant respondents was those that had visited the Adityawaraman Museum twice, namely 69 people (44\%)

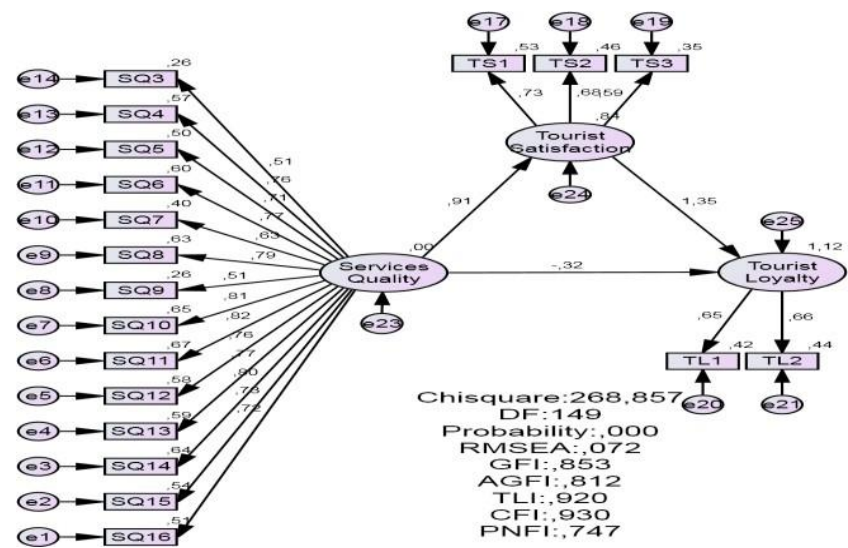

Figure 3. Full Model - Structural Equating Modeling (SEM)

Tests on the feasibility of carrying this model following the info or fit the information utilized in the study are as shown within the table below:

Table 4. Structural Equating Model (SEM)

\begin{tabular}{|c|c|c|c|}
\hline $\begin{array}{c}\text { Goodness of Fit } \\
\text { Index }\end{array}$ & $\begin{array}{c}\text { Cut-off } \\
\text { Value }\end{array}$ & $\begin{array}{c}\text { Analysis } \\
\text { Results }\end{array}$ & $\begin{array}{c}\text { Model } \\
\text { Evaluation }\end{array}$ \\
\hline Chi-Square & $>1.96$ & 268,857 & Fit \\
\hline Probability & $\geq 0.05$ & 0.000 & Fit \\
\hline RMSEA & $\leq 0.08$ & 0.072 & Fit \\
\hline GFI & $\geq 0.90$ & 0.853 & Marginal \\
\hline AGFI & $\geq 0.80$ & 0.812 & Fit \\
\hline TLI & $\geq 0.90$ & 0.920 & Fit \\
\hline CFI & $\geq 0.90$ & 0.930 & Fit \\
\hline PNFI & $0.60-$ & 0.747 & Fit \\
& 0.90 & & \\
\hline
\end{tabular}

Based on table 4. shows that the model used is employed. Chi-square value of 355,073 is larger than 1.96 and a probability of 0,000 but 0.05 is interpreted structural equation model as an honest. Probability results indicate that there is no difference between the sample covariance matrix and so the population covariance matrix estimated in.

Table 5. Regression Weight

\begin{tabular}{|l|c|c|c|c|}
\hline \multicolumn{2}{|c|}{ Estimate } & S.E & C.R & P \\
\hline $\begin{array}{l}\text { Services quality } \rightarrow \\
\text { Tourist satisfaction }\end{array}$ &, 936 &, 116 & 8,050 & $* * *$ \\
\hline $\begin{array}{l}\text { Tourist satisfaction } \rightarrow \\
\text { Tourist Loyalty }\end{array}$ & 1,205 &, 561 & 2,148 &, 032 \\
\hline $\begin{array}{l}\text { Services quality } \rightarrow \\
\text { Tourist Loyalty }\end{array}$ &,- 296 &, 519 &,- 570 &, 568 \\
\hline
\end{tabular}

\section{Hypothesis 1}

The estimated parameter of the connection between service quality and tourist satisfaction is 0.936 . The study of the connection between the two variables shows the price of $\mathrm{CR}=8,050$ with probability $=0.000(\mathrm{p}<0.05)$. So it's interpreted that service quality includes a positive effect on 
tourist satisfaction, therefore the higher the service received by tourists, the upper the satisfaction of tourists for tourist attractions. Thus hypothesis 1 is accepted because there is a positive influence between service quality and tourist satisfaction.

\section{Hypothesis 2}

Parameter estimated the link between service quality and tourist loyalty obtained by -0.296 . The study of the connection between the two variables shows the price of $\mathrm{CR}=-0.570$ with probability $=0.568(\mathrm{P}>0.05)$. So it's interpreted that service quality doesn't have a positive effect on tourist loyalty. This explains that there is no direct effect between service qualities on tourist loyalty. Thus hypothesis 2 is rejected.

\section{Hypothesis 3}

Parameter estimates the connection between tourist satisfaction and tourist loyalty obtained at 1,205 . The study of the connection between the two variables shows the price of $\mathrm{CR}=2.148$ with probability $=0.032(\mathrm{p}<0.05)$. So it's interpreted that tourist satisfaction incorporates a positive effect on tourist loyalty, therefore the upper satisfaction is owned by tourists, the upper the loyalty of tourists to tourist attractions. Thus hypothesis 3 is accepted because there is a correlation between service quality and tourist loyalty.

\section{Hypothesis 4}

Parameter estimation on standardized indirect effect shows that there is a between variables service quality on tourist loyalty through tourist satisfaction of 1,232. So it's interpreted that service quality contains a positive effect fully mediation on tourist loyalty through tourist satisfaction. Then hypothesis 4 is accepted.

\subsection{Discussion}

The study concluded that service quality encompasses a big direct effect on tourist satisfaction, service quality incorporates a big effect on tourist satisfaction, and tourist satisfaction incorporates a major effect on tourist loyalty. Then for the indirect effect, service quality has an indirect effect on tourist loyalty through tourist satisfaction. Tourists as individuals who use or use services have various considerations decide which tourist attraction to choose on they visited, began to figure out from the form of attractions, reliability, responsiveness, guarantees to the officials of the tourist attraction. After all, this has become a challenge for tourism management agencies to be able to provide quality services and under tourists' expectations, so they are going to be able to maintain their presence within the tourism business

The findings of this study prove that the tourist satisfaction of the Adityawarman Museum attraction is often determined by the quality of services provided by the manager of the tourist attraction. This study is strengthened by the opinion of Lovelock and Wirtz (2011), he stated that service quality is also a multi-dimensional construct consisting of 5 components, namely tangible, reliability, responsiveness, assertiveness, and empathy.

This research is additionally in line with research conducted by several other researchers like research conducted by Cloud (2011), Ganguli (2011), Caruana (2002), Valle, et al, (2006), Kahavarz and Ali (2016), and Melinda. (2017), who revealed that service quality contains a positive effect on satisfaction.

Increases and reduces in visitors to the Adityawarman museum there is not any direct relationship with service quality on tourist loyalty, this could be in line with research conducted by Chang et al, (2015), Melinda (2017), Velez et all (2018) revealed that service quality no direct effect on loyalty. Although it doesn't have an on the spot effect between services quality on loyalty, it's recommended that tourism object managers still hear the quality of the services they supply to tourists, because service quality affects satisfaction and so the effect of satisfaction is loyalty. This implies that the findings reveal that the quality of service doesn't provide meaning and contribution to tourist loyalty directly.

Bowen and Chen (2001), found that an increase in customer satisfaction led to an increase in customer loyalty. This study is additionally strengthened by the opinion of Valle et al, (2006) which states that loyalty might be a multi-dimensional contract which can be measured from intentions to return, willingness to recommended and continued by the opinion of Schmid in Paliati (2004) which states that loyalty is also seen from the influence word of mouth (worth of mouth positive).

This study is additionally in line with research conducted by several other studies like research conducted by Jimanto and Kunto (2016), Vinita (2005), Makanyeza (2017), and Melinda (2017), which show that satisfaction encompasses a positive effect on loyalty.

This research shows that the upper the quality services provided by service providers will regain tourist satisfaction that's felt by tourists when tourists have reached the stage of "satisfied" then he will become a tourist loyal to the tourist attraction. Measuring the loyalty of a tourist is going to be seen from the intention to return (the desire to return), willingness to recommended (recommend to others), and positive WOM (say positive things). When tourists are at the loyal stage, then this could benefit tourism object management, because the formation of tourist loyalty or loyalty will make a heavy contribution to the survival of the tourist attraction.

Lupiyoadi (2012), who revealed that perceived satisfaction was the result of the comparison of product/service performance with consumer expectations, satisfaction may be a mediating variable that connects service quality with loyalty.

This study is in line with research conducted by Caruana (2002) and Velez et al (2018), Kartika (2014), Melinda (2017), and Sawitri (2013) who revealed that service quality incorporates a positive effect on tourist loyalty mediated by tourist satisfaction. 


\subsection{After the Research Model}

Based on the results of testing on each research variable using AMOS 23 software supported structural equating modeling (SEM) approach and touching on the research hypothesis stated earlier which states that there's no direct effect between variable tourist loyalties with tourist satisfaction.

Therefore a post-research model may be made which shows that variables - the research variables influence each other. The research model of the research is often described as follows:

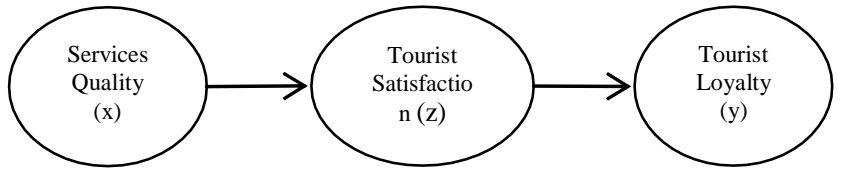

Figure 4. Conceptual Framework Model after Research

The above model shows the connection of influence on the variable of tourist loyalty, which refers to the results of the analysis of the best effect produced by service quality and tourist satisfaction so on form tourist loyalty.

\section{CONCLUSION}

The importance of service quality, makes tourists feel satisfied and dependable to attractions. the present study provides a model that aims to produce a much better understanding of the role of tourist satisfaction in mediating the link between service quality and tourist loyalty within the Adityawarman Museum attraction.

The relationship between the three constructs within the model is presented in Figure 2. The results of the study are as follows:

- Services quality incorporates a positive and significant effect on tourist satisfaction

- Services quality has no positive and significant effect on tourist loyalty

- Tourist satisfaction incorporates a positive and significant effect on tourist loyalty

- Tourist satisfaction has mediated within the relationship between Services quality and tourist loyalty.

Continued research may be done by viewing the restrictions during this study which might be a source of ideas for future research development. The expansion of research suggested from this study is to broaden the reach of research objects, not just to look at only 1 tourist attraction. additionally, in future studies, it's better to extend the number of respondents to extend the worth of AGFI to indicate a fit (not marginal) value.

\section{ACKNOWLEDGMENTS}

\author{
1.Thanks for my self and team
}

2.Thanks for Indonesian

3.Thanks for the Head of UPTD Museum Adityawarman who has allowed the writer to do this research.

\section{REFERENCES}

[1] Baker. DA. \& Crompton. JL, "Quality, satisfaction, and behavior intentions Annals of Tourism Research". 2000. 27 (3) 785-804

[2] Bigne, J. Enrique, Sanchez, M. Isabel, Sanchez, Javier. 2001. "Tourism image evaluation variables and after purchase behavior". Journal of tourism management; 22 (2001) 607-616.

[3] Bitner, MJ, Booms, BH and Stanfield, TM. 1990. "The service encounter: diagnosing favorable and unfavorable incidents". Journal of Marketing, Vol. 54 No. 1, pp. 71-84.

[4] Caruana, A. "Service loyalty: The effects of service quality and the mediating role of customer satisfaction". European Journal of Marketing; 36 (7/8), 811-828. 2002. https://doi.org/10.1108/03090560210430818

[5] Chuang, C., Chuang, W., \& Lin, W. 2015. "Total Quality Management \& Business Excellence An examination of the effects of quality on customer loyalty: the automobile industry in Taiwan”. (April), $37-$ 41. https://doi.org/10.1080/14783363.2012.704268

[6] Dick, AS and Basu, K., 1994. "Customer Loyalty: Toward an Integrated Conceptual Framework". Journal of The Academy Marketing Science, Vol. 22, p.99-113.

[7] Fornell , C. 1992. “A National Customer Satisfaction Barometer: The Swedish. Experience". Journal of Marketing, Vol. 56

[8] Ghozali, 2008. "Structural Equation Modeling: Theory, Concepts and Applications with AMOS Programs". Diponegoro University Publisher. Semarang

[9] Ganguli, S., \& Roy, SK. 2011. “Generic technologybased service quality dimensions in banking Impact on customer satisfaction and loyalty". https://doi.org/10.1108/02652321111107648

[10] Gallarza, MG, \& Gil Saura, I. 2006. "Value dimensions, perceived value, satisfaction and loyalty: an 
investigation of university students' travel behavior". Tourism Management, 27 (3): 437-452

[11] Gronroos, C. 1984. “A Service Quality Model and Its Marketing Implications". European Journal of Marketing, Vol 18, 36-44.

[12] Kartikasari, D., Dewanto, A., \& Rochman, F. 2014. "Effect of Service Quality on Satisfaction and Trust in Bunda Kandangan Hospital”, Surabaya. 12 (September).

[13] Keshavez, Yousef and Hareeza M, Ali. 2015. "The Service Quality Evaluation on Tourist Loyalty in Malaysian Hotels by the Mediating Role of Tourist Satisfaction". Mediterranean Journal of Social Sciences, Volume 6, No 3, pp 680-686

[14] Kozak, M. \& Rimmington, M. 2000. “Tourist satisfaction with Mallorca, Spain, as an offseasonholiday destination". Journal of Travel Research, 38 (3): 260-269

[15] Kotler, Philip and Gary Amstrong. 2016. "PrinsipPrinsip Pemasaran”. Edisi 13. Jilid 1. Jakarta: Erlangga

[16] Lupiyoadi, Rambat. 2013. "Manajemen Pemasaran Jas Berbasis Kompetensi”. Jakarta: Salembah Empat

[17] Makanyeza, C. 2017. "Determination of Consumers' Intention to Adopt Mobile Banking Services in Zimbabwe". International Journal of Bank Marketing, 35, 997-1017. https://doi.org/10.1108/IJBM07-2016-0099

[18] Melinda. 2017. "Pengaruh E-Service Quality terhadap E-Loyalty pelanggan Go-Jek Melalui ESatisfactionpada Kategori Go-Ride”. 2017. Journal AGORA Vol. 5, No. 1.

[19] Ministry of Foreign Affairs of the Republic of Indonesia. 2019. World Tourism Organization (UNWTO).https://kemlu.go.id/portal/id/read/135/halaman_li st_other/world- tourism-organization-un-wto accessed No. 1 October 2019
[20] Mossberg, L. 2007. "Marketing Approach to the Tourist Experience". Scandinavian Journal of Hospitality and Tourism, 7 (1), 59-74.

[21] Oliver, Richard L. 1999. "Whence Consumer Loyalty. Journal of Marketing., Volume 63 Special Issue, pp. 33-44. Parasuraman, A \& Zeithaml, VA, Berry, LL 1988. The Behavioral Consequences of Service Quality. Journal of Marketing”; 60 (2), 31-46

[22] Parasuraman, et. Al. 1988. "SERVQUAL: A Multiple-Item Scale for Measuring Consumer"

[23] Sawitri, N. P., Nyoman, N.,et al;. 2013. "Terhadap Kepuasan Dan Loyalitas Pelanggan Tegal Sari Accommodation Di Ubud". 7(1), 40-47.

[24] Sugiyono. 2014. "Metode Kualitatif, Kuantitafif Dan Kombinasi (Mixed Methods"). Bandung: Alfabeta.

[25] Um, S., et.al. 2006. "An attitude determinants in tourism destination choice. Annals of Tourism Research”. 17: 432-448

[26] Valle et al. 2006. "Tourist Satisfaction and Destination Loyalty Intention: A Structural and Categorical Analysis. International Journal of Business Science and Applied Management", 1 (1), 25- 44. Http://Business-And- Management.Org/Library/200 6 / 1_1-- 25-44 - Oom_Do_Valle, Silva, Mendes, Guerreiro.

[27] Vélez, Reyes PE Pérez Naranjo, LM, \& Rodríguez Zapatero, M, 2018. "The impact of daily tour service quality on tourist satisfaction and behavioral intentions in an island context: a study on tours to Isla de la Plata, Ecuador, Current Issues in Tourism".

[28] Yoon Y and Uysal, M. 2005. "An examination of the effects of motivation and satisfaction testing loyalty: A structural model. Tourism Management"; 26, 45-56. 